\title{
Europe should welcome diversity
}

With the arrival of three new members to the European Union, universities could be the centrepiece of a common purpose providing Europe with cultural cement.

THE best thing to have happened to the European Union since the ratification of the Maastricht Treaty last November is the prospect that Austria, Finland and Sweden will now become members. The three governments agreed terms with Brussels some weeks ago; later this year they will each hold a referendum to win assent to what is planned. If all goes well, the result will be not merely that the European Union spans the whole of Europe in two orthogonal directions, from North to South and East to West, but that the accession of these particular new members will lend the European Union a welcome degree of further diversity. Austria is not a little Germany to the East, but has become an enterprising and innovative economy in an historic setting. The two Scandinavian countries will similarly bring to the rest of Europe substantial and successful research enterprises and, more important, strong traditions of rationality in the management of public affairs that are not always conspicuous elsewhere.

But why should Europe welcome diversity when an excess of that commodity is one of its perennial problems? How will the European Commission ever be able to create a sense of European "identity" (one of its goals) when new members, speaking languages not yet on the translation roster at Brussels, are forever arriving on the doorstep? The answer is simple; Europe is not a "nation" (as are, for example, the Scots and the Sioux), and cannot become one even in the next millennium. Nor is there an easy way of smoothing over the differences of language within Europe, either by pretending that they do not matter or by fostering polyglotism.

The European Commission's line for the past few years has been to identify and then proclaim common elements in European cultural history. But even that is not straightforward. Knowing that Roman armies once occupied almost everywhere in Europe does not create a common sense of purpose among the descendants of the survivors of those regimes. Indeed, as social anthropologist Chris Shore from the University of London has recently argued ( $\operatorname{Man} \mathbf{2 8 , 7 7 9}$ $800 ; 1993)$, preoccupation with common culture may be as powerful a spur to xenophobia as to identity. A related difficulty is that the past, important though it is, by necessity gives people preoccupied with jobs and other contemporary problems a sense of being separated from a more delectable past.

So where should the European Commission be looking for cultural cement? For one thing, in the present. For another, in enterprises that promise something for now and for the future. So why not make the cause of the European university the centrepiece of an attempt to give all Europeans a sense of common, in multilingual, purpose? In some respects, the commission has had this idea already. There is an excellent and substantial programme for the transfer of students among European universities, for example. Many of the commission's research programmes are similarly angled at multinationality. But there as not yet been a serious attempt to harness these sporadic initiatives into a coherent whole. The arrival on the scene of three new and interesting member states should be a spur to that end.

Several issues need attention, and can be given it now that the Maastricht Treaty gives the European Union competence in the field. The temptation will be to devise ways in which students can become even more mobile than they are at present, perhaps by legislating for modular courses that students can follow here or there. But that is the wrong direction; universities also need diversity. But mobility for teachers, only partly addressed by the commission's present programme on human mobility, is a more urgent need. So are the tools of scholarship, from libraries in the oldfashioned sense to information super-highways in the modern. But while initiatives such as these could make academics feel good, would they not alienate the less fortunate who worry about jobs for themselves and their children. When the participation rate of the young in Europe is around 30 per cent, that would be the opposite of the truth.

\section{FDA lights Smoking Fire}

The US Food and Drug Administration is thinking about defining cigarettes as drug "delivery devices".

IN what is a bold move by any standards, David Kessler, the commissioner of the US Food and Drug Administration (FDA) has ventured the opinion that cigarettes might be legally defined as drug delivery devices, thereby subject to FDA regulation. Inasmuch as cigarettes deliver an addictive drug-namely nicotine--FDA regulation would be tantamount to a ban on the sale of cigarettes nationwide.

In a controversial letter to an antismoking coalition, Kessler recently said that there is evidence manufacturers "commonly add nicotine to cigarettes." This is so. After all, people do not smoke tobacco leaves whole. Rather, manu- 